\title{
FROM PERSPECTIVE DRAWING TO LOW COST PHOTOGRAMMETRY: APPLICATION IN ARCHITECTURAL STUDIES
}

\author{
M. Zammel ${ }^{1}$ \\ ${ }^{1}$ ENAU, National school of architecture and urban planning, Rue El Quods,Sidi Bou Said , Tunisia. meriem.zammel@ gmail.com
}

\section{Commission II}

KEY WORDS: Descriptive geometry, Perspective drawing, Low cost photogrammetry, 3D.

\begin{abstract}
:
Nowadays digital tools are booming. The evolution of the technologies used in archeology and in architecture is such that we are going more and more towards low cost and time saving. Indeed, today we can use free softwares in photogrammetry in order to make 3D surveys of architectural buildings. Fifteen years ago it only required the use of the 3D laser scanner, a very expensive technique. As part of the course reform of the second year at the national school of architecture and urban planning Tunisia in the course of descriptive geometry and perspective drawing, an experiment was conducted in order to introduce low cost photogrammetry using the free software $123 \mathrm{D}$ catch by autodesk, 3DF Zephyr or Scann 3D on the mobile phone. The objective of this course is to make students experiment different techniques of representation such as photogrammetry, perspective drawing, using a mobile phone , a digital camera or a pen. The object of the representation is the Tunisian cultural heritage such as the archeological site of Carthage.
\end{abstract}

\section{AIM OF THE COURSE}

\subsection{What is Descriptive geometry?}

Descriptive geometry has been invented by the French engineer mathematician Monge (1746-1818) which developed its principles. It's the study of the representation of the space on a plan.

Its aim is to represent space figure on plans projection. Descriptive geometry is useful for architects and engineers in order to represent space and architectural buildings in plan and elevation.

This course develops imagination in student's minds. In deed the precision of the drawings made using the pen and the rule make them experiment accurate representations.

Teaching descriptive geometry remains in the architectural studies since the XIX century and we are wondering if it is useful with the appearance of digital tools and 3D. In deed that we can say, that descriptive geometry develops imagination what is useful in front of a screen to represent 3D models. More over the rigor it requires is important for architectural drawings.

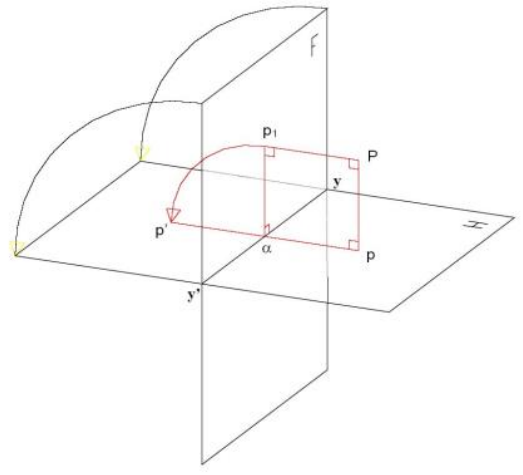

Figure 1-One point on plans projection
A new representation technique appears when we found a new method to represent point in space (Saint Auubin, 1992).

The course program starts by the representation of a points with its coordinate $(x, y, z)$. then the representation of a line, the intersection of two straight, the intersection of two plans, the intersection of volumes and perspective drawings (Aubert, 1996).

This course was a little bit abstract, so we introduce digital 3D tools and photogrammetry in order to apply the course on architectural buildings especially cultural heritage with its history and knowledge.

\subsection{Perspective drawing}

The perspective drawing is made from a single observer with two vanishing points. This prspective makes us visualise the $3 \mathrm{D}$ monument.

Using this representation method is important to understand fondamentals of 3D.

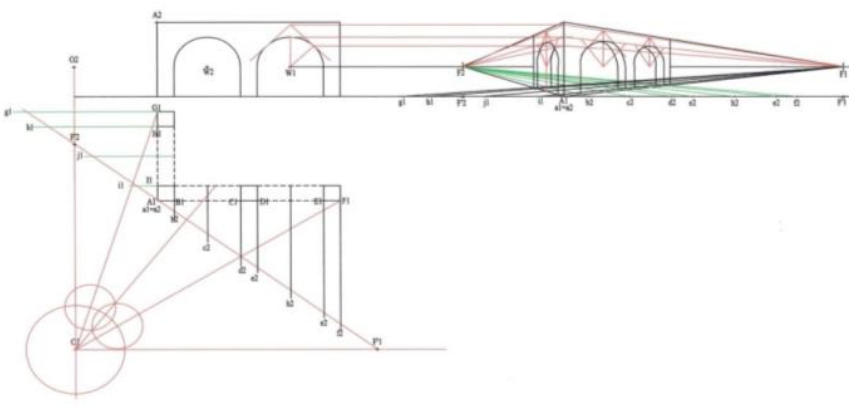

Figure 2- Method of perspective drawing 


\subsection{Multiple representation}

The representation of each architectural element has been obtained since multiple data sources. The representation of architecture is no matter a two dimensional graph, it's now possible to represent and describe of each part using 3D modeling. Image based modeling of the principal elements of the building has been made in order to represent complex geometric surfaces texture, materials. Multi-representation (De Luca, 2006) aims to use different kind of representation in order to show the final result from different data sources. In this exercise, students use low cost photogrammetry, perspective drawing using a pen and manual survey.

\section{INNOVATION IN THE COURSE: THE RESULTS}

\subsection{Site presentation}

The Carthage site is on the UNESCO World Heritage List since 1979.

This site experimentation was composed by site museum of Carthage, in the byrsa Hill and aristocratic roman villa: The villa of the aviary.

The site museum of Carthage

Carthage national museum is a national museum in Byrsa, Tunisia. Along with the Bardo National Museum, it is one of the two main local archaeological museums in the region. The edifice sits a top Byrsa Hill, in the heart of the city of Carthage. Founded in 1875, it houses many archaeological items from the Punic era and other periods.The Carthage National Museum is located near the Cathedral of Saint-Louis of Carthage. It allows visitors to appreciate the magnitude of the city during the Punic and Roman eras. Some of the best pieces found in excavations are limestone/marble carvings, depicting animals, plants and even human sculptures. Of special note is a marble sarcophagus of a priest and priestess from the 3rd century $\mathrm{BC}$, discovered in the necropolis of Carthage. The Museum also has a noted collection of masks and jewelry in cast glass, Roman mosaics including the famous "Lady of Carthage", a vast collection of Roman amphoras. It also contains numerous local items from the period of the Byzantine Empire. Also on display are objects of ivory.

The villa of the aviary

The villa of the aviary is located in the park of the roman villas in Carthage. This villa is the main element of the park, by the quality of the restoration carried out in 1960 (Ennabli, Slim, 1993). The name of the villa comes from the mosaic aviary marked by the presence of birds among leaves (Picard, 1951), which occupies the garden, in the middle of the viridarium, heart of courtyard surrounded by a portico of pink marble columns.

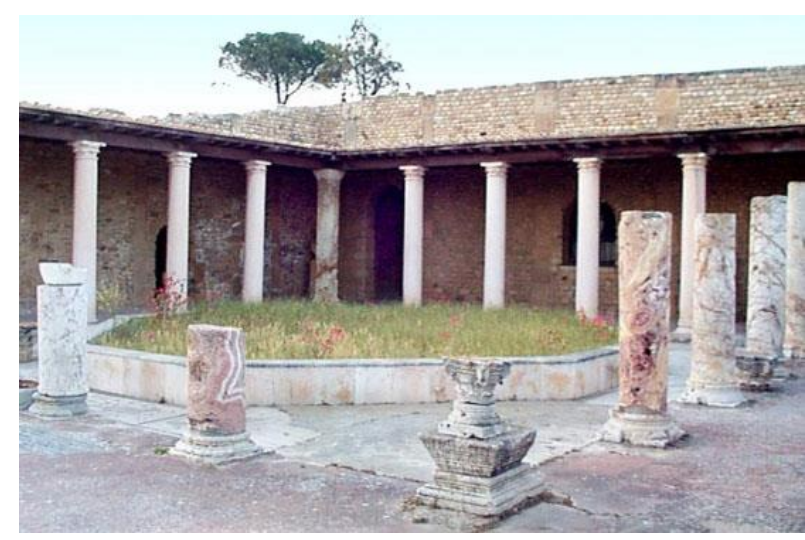

Figure 3- Picture of the villa of the aviary

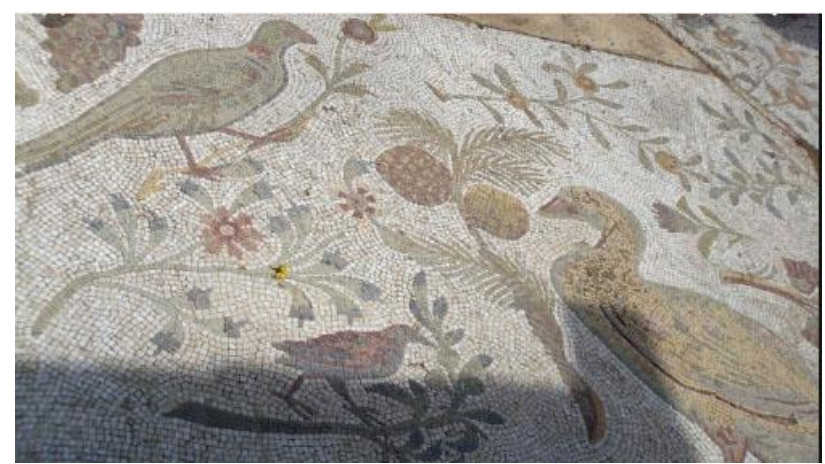

Figure 4- Mosaic of the villa of the aviary

\subsection{The manual drawing and perspective}

Using the perspective methods students can also, use colors in order to represent texture and materials. On the basis of the manual architectural survey, a 2D representation (plans, elevation) was produced before going on with the 3D modelling of each architectural element.

In order to experiment the representation technique from the manual survey, as well as 3D modelling and image based modelling we choose statues from the villa of the aviary as well as details small architectural elements.

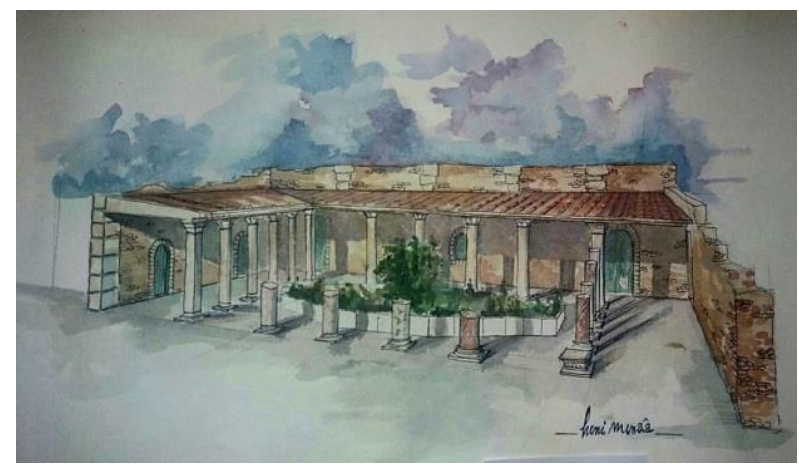

Figure 5- Perspective drawing with colors of the villa of the aviary 


\subsection{Teaching low cost photogrammetry}

Photogrammetric restitution allows extracting from the pictures a set of coordinate expressed in model space (Grussenmeyer et al.2001).

Students are invited not only to make perspective drawing using a pen but also low cost photogrammetry using the free softwares. Perspective drawing is made from a single observer, photomodelling allows a succession of views from digital photography taken all around the object. Low cost free software such as $123 \mathrm{D}$ catch by Autodesk, 3DF Zephyr and Scann 3D used in automatic photomodelling are able to render the $3 \mathrm{D}$ scene, to replace the camera lens, to make 3D models accurate and true to reality. The cameras are calibrated in order to replace the architectural object in the scene 3D. A similar study untitled: Descriptive geometry meets computer vision (Stachel, 2006), explains the link between descriptive geometry and image based modeling. What is innovative in this paper is that we use free low cost software with automatic photogrammetry The methodology developed in the course begins first by doing digital photographs using the mobile phone in the free software scann 3D all around the objects, the software shows red and green points on the screen when the images are calibrated and in right position. And then the $3 \mathrm{D}$ model appears on the phone and we can use the free software Zephyr 3D in order to take those photographs well calibrated from the mobile phone and introduce its on the laptop in order to have $3 \mathrm{~d}$ models using zephyr 3D, point cloud models and videos.

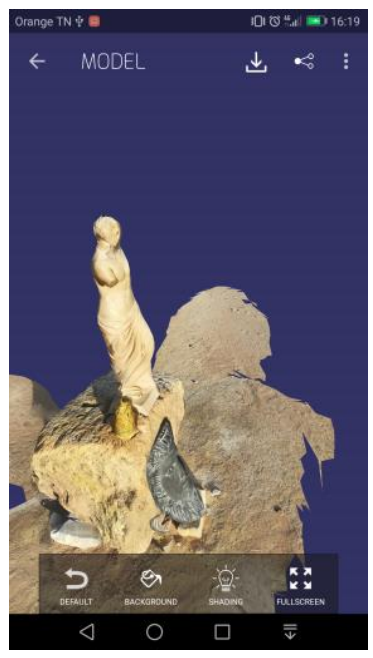

Figure 6- Photomodelling of a statue in the site museum of Carthage using Scann 3D.

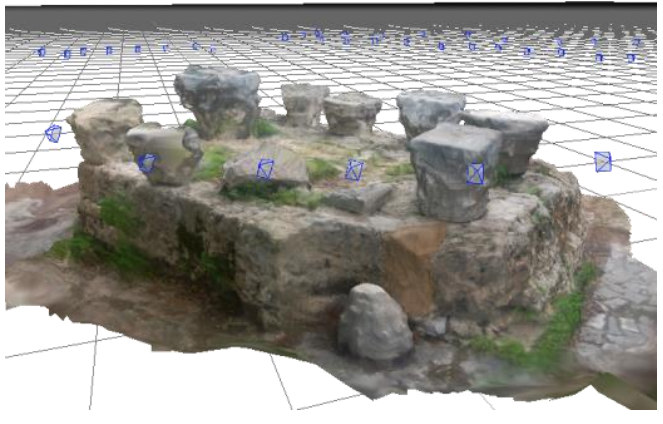

Figure 7- Photomodelling of capitals in the site museum of Carthage using Zephyr 3D.

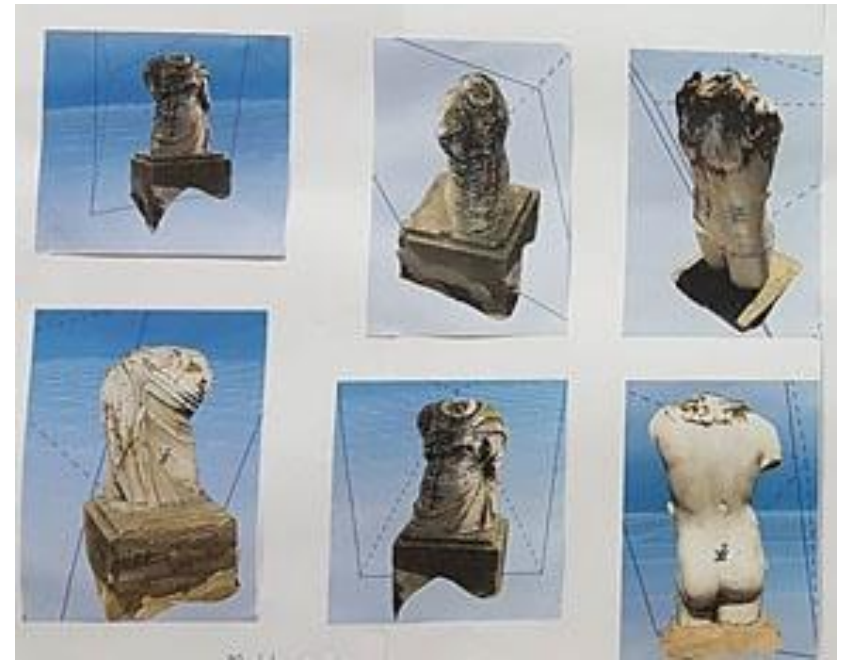

Figure 8- Photomodeling of statues of the villa of the aviary using 123 D Catch by autodesk.

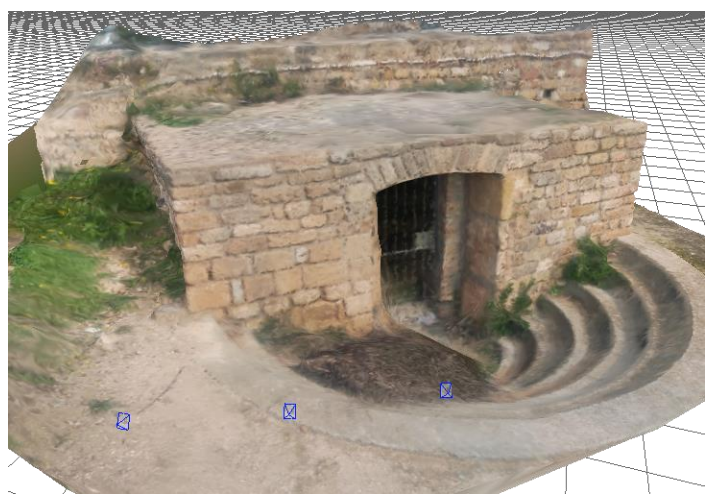

Figure 9- Photomodeling of a house in the site museum of Carthage using Zephyr 3D. 


\section{PERSPECTIVES}

\subsection{Image based modelling of the Tunisian cultural heritage}

In this experimentation our aim is to represent hole Tunisian cultural heritage using low cost photogrammetry. Tunisia is rich in cultural heritage, such as archeological sites, medinas We have a lot of students each year and we can change site experimentation and work on different sites. Our aim is to do internet archives of Tunisian cultural heritage sites.

\subsection{Internet archives}

And then our purpose is to share those photomodellings of the Tunisian cultural heritage on sketchfab whish can share photomodellings on internet and make people see those objects. This free software low cost make people share photomodelling of objets all over the world it can be useful for informat -.. technology.

\subsection{Memory}

Working on cultural heritage aims to bring knowledge about history, culture and to share commun memory of the people in the world. Architectural and archeological buildings are not limited to their representation it also includes knowledge (De Luca, L. 2006). This knowledge is usefull for new generations.

\section{CONCLUSION}

It don't exist one but multiple representations. Whith the evolutions of representation techniques in the domain of architecture we'll find other innovative methods that will appears This experimentation using low cost photogrammetry was very interesting for students. They were very happy to use there mobile phones, the computer, free softwares. With the appearance of such digital tools we can also obtain 3D models accurate and true to reality. In the new aims of the course we will introduce lasergrammetry when it will be low cost. Because we could have the hole monument more precisely. Internet archives of cultural heritage in Tunisia and in the world is a good challenge to documenting the past.

\section{REFERENCES}

Aubert, J., 1996. Dessin d'Architecture à partir de la géométrie descriptive, Editions de la villette, Paris France, $163 p$.

Cardinale, T., Valva, R., and Lucarelli, M. 2013, Advanced representation technologies applied to the temple of Neptune, The sphinx, and the meteope in the archeological park of Paestum, Photogramm. Remote Sens. Spatial Inf. Sci., XL5/W1, 35-41, https://doi.org/10.5194/isprsarchives-XL-5-W135-2013, 2013.

Casu P. and Pisu C., 2013. photomodelling and cloud computing application in the survey of late gothic architectural elements, int-arch-photogramm-remote-sens-spatial-infsci.net/XL-5W1.
Casu, P. and Pisu, C. 2013. Photo modelling and cloud computing application in the survey of late gothic architectural elements. International Archives of the Photogrammetry, Remote Sensing and Spatial Information Sciences, Volume XL5/W1, 2013 3D-ARCH 2013 - 3D Virtual Reconstruction and Visualization of Complex Architectures, 25 - 26 February 2013, Trento, Italy.

De Domenico, F. 2006. De l'acquisition des données spatiales à la représentation architecturale : le cas des vestiges du théâtre antique d'Arles, Journal MIA, Vol.0, $n^{\circ} 1$.

De Luca, L. 2002. Relevé et représentation de l'architecture : Le capitole de Dougga. Rapport de mission Dougga, UMR 694 MAP.

De Luca, L. 2006. Structuration sémantique et multireprésentation en Architecture, Biarritz, virtual Retrospect

De Luca, L. 2009, La photomodélisation architecturale : Relevé, modélisation et représentation d'édifices à partir de photographies. Eyrolles, pp.264,

Grussenmeyer, P. Hanke, P. Russenmeyer, P. and Streilein A. 2001. Photogrammétrie architecturale, chapitre du livre, Photogrammétrie numérique. Editions Lavoisier-Hermès.

Saint Aubin, J.1992. Le relevé et la représentation de l'Architecture. Paris : Association Etudes, loisirs et Patrimoine, Documents et méthodes.

Scann 3D, Developpement Team 2017, open source Software.

Sketchfab, Developpement Team 2017, open source software.

Stachel, H., 2006. Descriptive Geometry meets computer vision- The geometry of multiple images, International conference on geometry and graphics, Salvador

Zammel, M. 2014. Apport des outils numériques dans l'étude des théâtres de l'Afrique romaine. Actes du colloque patrimoine et horizons, Gammarth, Tunisia.

Zammel, M., 2015. Photo modeling and cloud processing: Application in the survey of the roman Theatre of Uthina (Tunisia) architectural elements. Caa conference (Computer applications and quantitative methods in Archeology) 29 Mars au 03 Avril

Zammel, M.2015. Outils d'aide à l'étude architecturale des théâtres romains d'Afrique Approche comparative basée sur les nouvelles technologies de l'information et de la communication. Sarrebruk, Presses académiques francophones.

Zephyr 3DF, Developpement Team 2017, open source Software. 